\title{
Managing customer profitability using portfolio matrices
}

Received: 29th March, 2005

\section{Lawrence Ang}

is a senior lecturer at the Macquarie Graduate School of Management at the Macquarie University, Sydney, Australia. He researches in the area of customer relationship marketing, advertising effectiveness and branding. He consults regularly for Australian companies.

\section{Ben Taylor}

is a senior manager at a large internet service provider in Australia. He has worked extensively in the IT industries and is researching in the area of portfolio management.

Abstract Many companies have invested in systems such as enterprise resource planning (ERP) and customer relationship management (CRM) with the aim of managing their customers better. To do this well, however, a company must first understand customer profitability. This paper proposes a customer portfolio method of achieving this. Using a database of 130,000 customers from an internet service provider (ISP), this method demonstrates significant gains and returns on investments, by going beyond customer loyalty and instead advocating a proactive way of managing different customer groups based on their profitability.

\section{INTRODUCTION}

To date, although there has been an abundance of literature on managing customer relationships, ${ }^{1,2}$ less is known about managing profitable customers. One approach, termed the loyalty or retention approach, is a result of a backlash against the customer satisfaction approach. ${ }^{3}$ The loyalty approach basically argues that retention of customers is critically important to company growth and profit; for instance, it has been estimated that an increase in retention rate of as little as 5 per cent can lead to

Lawrence Ang

Macquarie Graduate School of Management, Macquarie University, NSW 2109, Australia.

Tel: +61 (0)2 98509135 ; Fax: +61 (0)2 98509019 ; e-mail:

Lawrence.ang@mq.edu.an an increase of between 25-95 per cent in net present value from a wide range of industries. ${ }^{4}$ The retention approach works because acquisition costs are often high; customers are barely profitable in the early stages of the company-customer relationship. With tenure, customer revenues typically increase, cost-to-service decreases for the organisation, referrals are given and customers often purchase premium or additional services. Therefore, as customers go through the relationship life cycle, the organisation receives more income and profit.

While it is generally true, that retention leads to higher profitability, however, it is by no means always the case. This is because some customers may be more profitable than others. Similarly, the satisfaction-profit chain, ${ }^{5}$ which says that customer satisfaction leads to loyalty, which in turn leads to higher profit may in fact be suboptimal if adopted across all customers. Storbacka et al. ${ }^{6}$ have criticised retention strategies as simplistic, 'The logic relies on the assumption that a customer relationship is 
profitable. Seeking to retain a hopelessly unprofitable customer in industries with continuous customer relationships cannot make business sense'. ${ }^{7}$ Some researchers even suggest that the contrary is true; more loyal customers may be less profitable and loyalty programmes may in fact be detrimental. ${ }^{8}$ Loyal customers demand rewards or discounts for their loyalty. 'Size' of customer (ie revenue) also does not necessarily equate to profit. The classic 80:20 rule, whilst generally true for both revenue and profit, may not originate from the same customers. For instance, large customers may not be the most profitable because they are more demanding, insist on onerous levels of servicing and may be persistent late payers. One study found that 20 per cent of customers are responsible for 225 per cent of the profits when activity-based costing is used. ${ }^{9}$ Another study found that up to 40 per cent of a company's revenue can, in fact, be derived from unprofitable customers if they are fully costed. ${ }^{10}$ Finally, very often companies use the profit earned from their best customers to subsidise their unprofitable customers. In retail banking, for instance, as many as 50 per cent of customers are unprofitable. ${ }^{11}$

\section{Customer portfolio analysis}

If not all customers are equally profitable, how does one go about managing this? One approach, which grew out of business-to-business (B2B) relationship marketing, was to develop customer portfolios, often using two or more dimensions. Depending on what measures were included in these dimensions, different matrices of customer segments would result.

Cunningham and Homse ${ }^{12}$ were among the earliest to develop such a matrix. They adopted the two dimensions of 'technical interaction' and 'sales volume', but did not include customer profitability. Another early model was that of Fiocca. ${ }^{13} \mathrm{He}$ suggested a two-step approach, first using the dimensions of 'difficulty in managing the account' and 'strategic importance' (stage 1). Then, when all the strategically important customers were identified (regardless of the difficulty in managing the account), they were further segmented into 'business attractiveness' and 'relationship strength'. Customer profitability was, however, not considered. The first model that came close to considering customer profitability was that of Shapiro et al. ${ }^{14}$ The dimensions used were 'cost-to- serve' and 'price received'. Customers whose 'cost-to-serve' was low but who were willing to pay a high price for the goods (ie high 'price received') were deemed to be the most profitable. Turnbull and Zolkiewski ${ }^{15}$ extended this model by including a third dimension, 'relationship value'. This third dimension allowed strategic judgements to be made, but suffered from subjectivity. Neither model had customer profitability as a major dimension.

The first model to explicitly include the 'customer profitability' dimension was that of Yorke and Droussiotis, ${ }^{16}$ which was based on the approach of Fiocca. ${ }^{17}$ Instead of using 'business attractiveness' in stage 2, they adopted 'customer profitability'. This model is static because future profitability was not considered. Conversely, Storbacka et al. ${ }^{18}$ injected a dynamic aspect into their model by including a 'relationship longevity' dimension to accompany their 'customer relationship profitability' dimension. To date, however, their model remains conceptual. Finally, Zeithaml et al. ${ }^{19}$ developed yet another idea for assessing firms' customer base, but one without the use of matrices; they used tiers of 'customer profitability'. They argue that 
the traditional $80: 20$ demarcation is only two-tier, which is often not sensitive enough. For optimal management, Zeithaml et al. suggested a four-tier division of customer profitability, ranging from the highest to the lowest and dubbed platinum, gold, iron and lead customers. This model also remains largely conceptual.

In summary, although there are many types of customer portfolio, each designed for its own purpose (see review in Turnbull and Zolkiewski ${ }^{20}$ ), they generally suffer from either being conceptual or too complicated - often without large scale validation (due in part to its B2B nature). Furthermore, with a few exceptions (eg Storbacka et al. ${ }^{21}$ ), the dimension of customer profitability and how it changes across time is not considered. This present paper reports the validation of a model in the context of business-to-consumer (B2C) marketing using a large database of 130,000 customers. This model takes two customer dimensions into considerations:

(a) gross margin of each customer; and (b) their length of tenure (ie time).

When combined these two dimensions yield four customer sets (see Table 1).

These are defined as:

1 Star - high margin customers with long tenure.

2 Supernova - high margin customers with short tenure.

3 Black hole - low margin customers with long tenure.

4 Eclipse - low margin customers with short tenure.

This matrix has a number of managerial implications. In general, the strategies are as follows:

- Star - treat them well with exceptional service (since they are the most coveted);
Table 1: Customer profitability mapping

\begin{tabular}{lll}
\hline & Low tenure & High tenure \\
\hline High margin & Supernova & Star \\
Low margin & Eclipse & Black hole \\
\hline
\end{tabular}

- Supernova - treat them well, but also encourage longer tenure (since they will be most susceptible to competitive offerings or substitutes);

- Black hole — reduce cost-to-serve, and/or up-sell and cross-sell other services in order to make them more profitable (since contractually or otherwise, the company is stuck with them);

- Eclipse - increase price or limit services in order to 'sack' these customers (since these customers cost the company money; migration can also be attempted).

\section{RESEARCH OBJECTIVES AND QUESTIONS}

The primary objective in this research is to test the customer profitability mapping (CPM) model. Principally this means mapping the profitability of different customers, experimenting with different strategies that will transform unprofitable customers and, finally, evaluating if all this leads to a greater overall company profitability. The specific research questions are:

1 CPM. Are some customers more profitable than others? Are loyal customers more profitable? Do certain behaviours determine profitability more than others?

2 Implementing strategies to current customers based on their profitability. Does changing the way customers are communicated with influence their behaviour?

3 Total company gross margin. Will the successful implementation of steps 1 
and 2 above lead to greater company profitability?

\section{METHODOLOGY}

\section{Total Base}

The data is based on approximately 130,000 customer names from an internet service provider (ISP).

\section{Data collection}

It took nearly six months, beginning in early 2003 , to build the data warehouse, including the purchase of capital equipment such as a computer server and software. All customer information (eg internet usage, number of contacts with call centre and billing information) are stored in this data warehouse.

\section{Formula}

The formula for calculating margins is based on the subscription service as follows:

- Revenue: monthly access fee + monthly excess fee

- Costs: monthly network costs + monthly credits issued + monthly technical support calls + monthly billing support calls

The result is the monthly customer gross margin.

The formula for calculating tenure was based on historical customer churn data within the company. There are two types of customers - contracts and casual. Contracted customers join for periods of six months or more and have exit penalties if they leave prior to the end of their contract. Casual customers pay month by month and can leave at any time. Note that acquisition costs are not included.
These are sunk costs, which need to be closely managed.

\section{Analysis}

The model was first run in July 2003, with customers modelled on their June 2003 data. One month prior to modelling, however, extensive testing was carried out to ensure accuracy. Financial data, like billing and costs of network and technical support, were based on the previous 12 months. All the tests were carried out over a ten-month period (July 2003 to May 2004).

\section{RESULTS}

The section below summarises the three major findings.

\section{CPM}

In June 2003, 44 per cent of the company's customer base contributed to gross margin. These are the stars $(33$ per cent) and supernovas (11 per cent). Fifty six per cent of the customer base; comprising of eclipses (14 per cent) and black holes (42 per cent) is unprofitable, however (see Figure 1).

Further analysis reveals that the Eclipse customer group is dominated by unprofitable customers. Out of the 14 per cent of customers making up this group, 10 per cent had negative gross margins. For the Black hole customers, out of 42 per cent, 20 per cent had negative gross margins. In summary, 30 per cent of the customer base (10 per cent Eclipse +20 per cent Black holes) had a negative gross margin.

\section{Implementing strategies to current customers based on their profitability}

After mapping the customer profitability, a series of tactics were 
Tenure

Low

$<6$ months and no contract

$>6$ months or under contract

\begin{tabular}{|l|l|c|c|}
\hline Actual & High & Supernova & Stars \\
gross margin & $40 \%+$ & $11 \%$ & $33 \%$ \\
$(\%)$ in current & & & \\
period & Low & Eclipse & Black holes \\
\cline { 3 - 4 } & or neg. & $(10 \%$ are negative $)$ & $42 \%$ \\
& & & $(20 \%$ are negative $)$ \\
\hline
\end{tabular}

Figure 1: Customer profitability mapping matrix

then implemented to better manage these groups.

\section{Super nova:}

- Encouraged contracts by offering lower priced service for entering a 12-month contract.

Results: Successfully achieved the migration of 19 per cent of the Supernova customers to Stars. Success was determined by whether or not they chose a contract plan.

\section{Black hole}

- Advertised benefits of online technical support and billing information to help reduce calls to the call centre.

- Advertised benefits of higher priced plans that come with additional features.

Results: A 16 per cent reduction in the number of negative margin Black hole customers. Instead of draining margin, they now contributed to margin.

\section{Stars}

- Maintained high level of service ensured that call centre staff were able to identify these customers and treat them with particular care.

- Provided avenues for advocacy encouraged them to talk to other non-customers about joining by providing free trial offers for them to pass onto their friends. (Eg introduced a sign-on-a-friend campaign.)

Results: Only a small group became Advocates. Overall, the Star customers group grew by 12 per cent due to migration from the Supernova and Black hole groups.

\section{Eclipse}

Different strategies were used for the two sub-categories: 
- Negative gross margin customers make them pay more to use current services through a price rise.

- Positive gross margin customers limit their current service and encourage them to pay slightly more by moving to an unrestricted plan.

Results: The number of Eclipse customers remained largely the same, due to the acquisition plan of attracting new customers through a free trial. The above pricing activities, however, were carried out just prior to the end of the trial period. Eighteen per cent of Eclipses moved to Supernova or Star status.

\section{Total company gross margin}

After the first quarter of implementation, total company gross margin (which is defined as the sum of all gross customer margins) increased from 31.7 per cent to 34.1 per cent. This represents a 7.5 per cent improvement and can be translated into an annualised increase of $\$ 800,000$ in gross margin. Furthermore, the cost of all these tactical implementations was approximately $\$ 85,000$, representing a return on investment of under two months.

\section{CONCLUSION}

There are many positive indicators that CPM works. This study has a number of implications. First, it demonstrates that using length of tenure (or customer loyalty) to calculate profitability may be misleading, since it will lead to the inclusion of long term unprofitable customers. Secondly, it demonstrates the importance of keeping good records of customer revenue and cost at the individual level — without which profitability customer mapping will not be possible. Thirdly, it demonstrates the importance of setting specific goals for certain customer groups, like turning low or negative margin customers into more profitable or viable customers. Finally, it demonstrates that if the profitability of all customer groups can be better managed, then it will lead to a better overall financial health of the company. An cautionary note is required, however, the results of this paper may not be generalisable to all services, but limited to those that are subjected to customer churn (eg mobile phones, internet services). Under such circumstances, timely management of customer profitability is critical.

\section{References}

1 Buttle, F. (2004) 'Customer relationship management - Concepts and tools', Elsevier, Butterworth-Heineman, Oxford, UK.

2 Brown, S. (2000) 'Customer relationship management', John Wiley \& Sons, Ontario, Canada.

3 Jones, T. and Sasser, W. (1995) 'Why satisfied customers defect', Harvard Business Review, Nov/Dec, pp. 88-99.

4 Reichheld, F. (1996) 'The loyalty effect: The hidden force behind growth, profits, and lasting value', Harvard Business School Press, Boston, MA.

5 Anderson, E. and Mittal, V. (2000) 'Strengthening the satisfaction-profit chain', Journal of Service Research, Vol. 3, No. 2, pp. 107-120.

6 Storbacka, K., Strandvik, T. and Gronroos, C. (1994) 'Managing customer relationships for profit: The dynamics of relationship quality', International Journal of Service Industry Management, Vol. 5, No. 5, pp. 21-38.

7 Storbacka et al. (1994) ibid., p. 31.

8 Dowling, G. and Uncles, M. (1997) 'Do customer loyalty programs really work?' Sloan Management Review, Vol. 38, No. 4, pp. 71-82.

9 Cooper, R. and Kaplan, R. (1991) 'Profit priorities from activity-based costings', Harvard Business Review, May/June, pp. 130-135.

10 Leszinski, R., Webster, F., Panganoni, R. and Baumgartner, T. (1995) 'Profits in your backyard', McKinsey Quarterly, Vol. 4, p. 118.

11 Storbacka et al. (1994) op. cit.

12 Cunningham, M. T. and Homse, E. (1982) 'Controlling the marketing-purchasing interface: Resource development and organisational implications', Industrial Marketing and Purchasing, Vol. 1, No. 2, pp. 3-27.

13 Fiocca, R. (1982) 'Account portfolio analysis for strategy development', Industrial Marketing Management, Vol. 11, pp. 53-62. 
14 Shapiro, B., Rangan, K., Moriaty, R. and Ross, E. (1987) 'Manage customers for profits (not just sales)', Harvard Business Review, September/October, pp. 101-108.

15 Turnbull, P. and Zolkeiwski, J. (1997) 'Profitability in customer portfolio planning', in Ford, D. (ed.) 'Understanding business markets', 2nd Edition, The Dryden Press, London, pp. 305-325.

16 Yorke, D. A. and Droussiotis, G. (1994) 'The use of customer portfolio theory: An empirical survey', Journal of Business and Industrial Marketing, Vol. 9, No. 3, pp. 6-18.

17 Fiocca (1982) op. cit.

18 Storbacka et al. (1994) op. cit.

19 Zeithaml, V., Rust, R. and Lemon, K. (2001)

'The customer pyramid: Creating and serving profitable customers', California Management

Review, Vol. 43, No. 4, pp. 118-142.

20 Turnbull and Zolheiwshi (1997) op. cit.

21 Storbacka et al. (1994) op. cit. 